\title{
'Best Interest of a Child' Doctrine in Divorce Cases: Resorting to family mediation practice
}

\author{
Norazlina Abdul Aziz 1, Nur Ezan Rahmat 1, Rozlinda Abdullah 1, Noor Huda Roslan 2 \\ ${ }^{1}$ Senior Lecturer, Faculty of Law, Universiti Teknologi MARA, 40450 Shah Alam, Selangor, Malaysia \\ 2 Head of Registrar of the Syariah Judiciary Department/ Syariah Court of Appeal, Selangor, Malaysia
}

noraz397@uitm.edu.my,nurezan@uitm.edu.my,rozlinda@uitm.edu.my,noorhuda@esyariah.gov.my

Tel of 1 st Author: 03- 55444122

\begin{abstract}
The best interest of the children in divorce cases may be best protected using the family mediation model. Although Malaysia has adopted the practice of mediation, it is not made compulsory for family disputes. This study aims at analyzing the effective interpretation of the 'best interest of a child' by replacing the adversarial platform with a family mediation platform. This study adopts a qualitative approach utilizing doctrinal study, content analysis, and interview. The outcome showed that there is a need to promote family mediation in Malaysia and this may assist the stakeholders in developing a harmonious platform for family disputes.
\end{abstract}

Keywords: Child's Rights, family mediation, divorce, developmental psychology

eISSN: 2398-4287@ 2020. The Authors. Published for AMER ABRA cE-Bs by e-International Publishing House, Ltd., UK. This is an open access article under the CC BYNC-ND license (http://creativecommons.org/licenses/by-nc-nd/4.0/). Peer-review under responsibility of AMER (Association of Malaysian Environment-Behaviour Researchers), ABRA (Association of Behavioural Researchers on Asians) and cE-Bs (Centre for Environment-Behaviour Studies), Faculty of Architecture, Planning \& Surveying, Universiti Teknologi MARA, Malaysia. DOI: https://doi.org/10.21834/ebpj.v5i15.2413.

\subsection{Introduction}

This paper is a result of a study that attempts to justify the need to address the best interest of the children to divorce through the mediation process. In 2019 the Department of Statistics, Malaysia (Press Release, 2019) revealed that the number of marriages increased by 1.2 percent from 203,741 in year 2017 to 206,253 in 2018 . Unfortunately, the divorce rate had also increased by $0.1 \%$ from 50,314 in 2017 to 50,356. Muslim divorce recorded in 2018, was 40,426, an increase of $1.4 \%$ as compared to 39,709 in 2019 . The divorce-related claim took place in court with the assistance of competing lawyers representing the couple in dispute. Children to the marriage usually remain unattended because they are not the party to claim ( $\mathrm{Ng}, \mathrm{K}$. and et. al, 2018). While deciding for claims relating to divorce, each party will usually uncover the horrible and hideous part of their spouse to impeach her/his credibility (Nadja Alexander, N., 2019; Ng, K. and et al, 2018; Ali, SF., 2019). In the claim for custody, the court will apply the rule of the 'best interest of the children' by looking at the ability to give good education, good living, and financial support. The parent with less ability to provide these amenities would usually lose in the battle of custody.

World trends witness the rapid replacement of courts' function in settling family disputes with the mediation process (Alexander,N. 2019). Singapore has long acknowledged the need to have mediation interference into legal proceedings in settling family disputes (Kevin Ng, K. and et. al, 2018; Chua, E. 2019). The aftermath of the utilization of mediation in resolving family disputes witnessed the increase in the percentage of divorce cases filed under the simplified track with no contested issues from $24 \%$ in 2015 to $37 \%$ in 2016 and $49 \%$ in 2017(Kevin Ng et. al, 2018). In Australia, most of the states have mediation practice embedded in its civil procedure statutes

eISSN: 2398-4287@ 2020. The Authors. Published for AMER ABRA cE-Bs by e-International Publishing House, Ltd., UK. This is an open access article under the CC BYNC-ND license (http://creativecommons.org/licenses/by-nc-nd/4.0/). Peer-review under responsibility of AMER (Association of Malaysian Environment-Behaviour Researchers), ABRA (Association of Behavioural Researchers on Asians) and cE-Bs (Centre for Environment-Behaviour Studies), Faculty of Architecture, Planning \& Surveying, Universiti Teknologi MARA, Malaysia.

DOI: https://doi.org/10.21834/ebpj.v5i15.2413. 
[Civil Procedure Act 2010(Vic), Civil Procedure Act 2005(NSW), Civil Procedure Act 2011(Cth)] in handling civil and family cases and expanding to criminal cases (Ojelabi, L.A, 2019).

\subsection{The Purpose of Study}

This paper analyses the fundamental basis in proposing family mediation to replace litigation with to preserve the best interest of children in divorce cases.

\subsection{The Objective of Study}

This study aims at providing enhanced justifications to propose the adoption of family mediation in addressing the divorce-related claims.

\subsection{Literature Review}

The psychological impact of children in divorce cases is not well addressed. The majority of the studies (Griffith, J., 2018; Cetinkaya, S. and Ercin, E. 2015; Owens, W. and Wanda, M., 2017; Emery, R.E., and Wyer, M. M, 2015) in the area of psychology agree that divorce negatively impacted the children's psychology. Before the court judgment, the children may witness the obnoxious discoveries of the parents' behavior. The recording of this unpleasant experience will later have an impact on the shaping of the children's psychological development. A national survey by the Ministry of Health (2015) revealed that Malaysian teens aged 13 to 17 are critically suffering from mental health problems. Peer pressure, harsh parenting styles, and family conflicts contributed to mental health issues among youths. According to a study by Sakinah, S., (2020), of all the reasons relating to mental health, the biggest reason that pressed them to the brink is family problems.

The literature agrees that the consequences of psychological vulnerability in children will increase the risk of crime and violence in late adolescence (Muscatello and et al., 2014; Nelson \& Brianna, L., 2013). The psychological development of children is significant in building future generations with high self-esteem and a high level of interpersonal trust. (Ng, K., and et al.,2018) Successful children are a future investment that will not only benefit the family but the country in general. Abundant of literature (Griffith, J., 2018; Sakinah,S., 2020; S. and Ercin, E. 2015; Carmela, M. and et. al, 2018) in psychology documents show the importance of these relationships of attachment between caregiver and children, especially for young children. A good body of case material and descriptive studies of groups of people who have experienced a loss of important ties demonstrate the existence of a pattern of problems now known as "attachment disorder." When there is a disruption of the ongoing importance of the relationship of attachment, the children respond negatively to future relationships. Alternatively, they may dismiss the importance of relationships and concentrate on independent activities and achievements at the expense of the future relationship.

Resorting to family mediation in settling a divorce-related claim is seen as the most appropriate start to preserve the children's psychological development. Mediation is an alternative platform to resolve a family dispute where its main objective is to sustain the relationship of the ex-spouses (McGowan D., 2018). It may assist in reducing the damage which results from the adversarial proceedings. Jolivet \& Randall, K., (2011), who writes on the advantages of mediation, mentioned that mediation is a voluntary and informal process in which a neutral third party assists in developing acceptable solutions.

\subsection{Methodology}

This study adopted a qualitative research methodology in which the primary data was obtained through semi-structured interviews with relevant officers from various departments namely the conciliators at the Department of Registration, mediators from the Malaysian Mediation Centre, Judges and Registrars of the High Court, and experts in this field. The secondary data was obtained from the statutes, books, journals and online articles. Children's psychological development are analyzed to support the adoption of mediation as the best mechanism in settling divorce-related claims. The Law Reform (Marriage and Divorce) Act 1976 and Mediation Rules, Code and Conduct by the Malaysian Mediation Centre were critically examined. The data have been analysed by using a content analysis approach.

\subsection{Findings and Discussion}

\subsection{Scope of Children and Their Limitation}

Generally, the term 'child' fits in many definitions depending on the nature of the discussion. Child, defined as a young person below the age of puberty or the legal age of majority (Oxford Dictionaries, 2018). The Free Dictionary online (2018) defines child as a person between birth and puberty who has not attained maturity or the age of legal majority. The general definition includes the legal age of the majority. These definitions mentioned the 'legal age of majority'.

The statutory definition of children appeared in the criminal and civil laws of Malaysia. For example, under the Child Act 2001, 'child' is defined as a person under the age of eighteen years, and concerning criminal proceedings, a child is a person who has attained the age of criminal responsibility as prescribed under section 82 of the Penal Code [Act 574]. Section 82 of the Penal Code provides that children below the age of ten cannot commit a crime. Their innocence is said to make them incapable of forming a guilty mind (Ismail, $\mathrm{N}$ and Abdul Aziz, N. 2009). In the Code, children aged between 11 to 12 years, must understand the nature and consequence of his conduct before they are charged with any offense. Therefore, the defense of the doli incapax (deemed incapable of forming the intent 
to commit a crime or torts, because of age) is not applicable. In criminal cases, children aged above ten years old and below sixteen, are termed as 'youthful offender' under the Criminal Procedure Code.

Looking into the civil law definition, Section 2 of the Age of Majority Act 1971 [Act 21], provides that the definition of children is those of 18 years and above. Similarly, sections 87 of the Law Reform (Marriage and Divorce) Act 1976[Act 164] define children as a person who is under the age of 18 years old. This is consistent with the definition provided under section 2 of the Domestic Violence Act 1994[Act 521]. The segregation of the child described above reflects that children would have different physical and mental abilities to carry out criminal or civil action. The main factor that contributes to the above classification is linked to their mental ability to differentiate what is right and wrong and the ability to foresee the future consequences of their actions. They are more easily controlled by emotion rather than mature thinking of oneself (Ismail, N. and Abdul Aziz, N. 2009). It is axiomatic that children are in the process of growing up, both physically and mentally. Children may know right from wrong of the adult sentences for children correctly parrot the phrase that it is "wrong" to kill, albeit often without any real understanding of what killing means or why it is wrong. Due to their immaturity, children have less developed capacities than adults to control their impulses. They are not able to use reason to guide their behavior and to think about the consequences of their conduct. They are, in short, still growing up. In addressing the rights of children to divorce, the above criteria need observation. Mediation can be a platform that may best suit the balancing need of parents to get a divorce and the rights of the children to have a promising future.

\subsection{Children of Divorce Psychological Development}

Research (Griffith, J., 2018; Cetinkaya, S. and Ercin, E. 2015; Sakinah,S., 2020) in developmental psychology tells us that children need stability and security. They are affected when they lose their ongoing intimate relationships with those adults who provide care and protection for them (Sakinah,S., 2020). The modern theories of aggression explain two possible reasons for an act of aggression suited to the discussion of this paper. Heightened tension and frustration are the two most relevant factors that will lead to aggressive action in a person. Ancient theories that introduce the frustration-aggression hypothesis explain that frustration will ignite the inner instinct to harm another. Children who are frustrated over the divorce of his/her parents have the possibility of committing an aggressive act unless consoled to accept the bitter destiny. Heightened tension has been identified by modern psychologists to be one of the reasons for commission an aggressive act. A child who has continuously witness the breaking-up process that has uncovered the unpleasant behavior of their parents may suffer heightened tension that will lead them to harm own self or another (Owens, W. and Wanda, M., 2017; Emery, R.E., and Wyer, M. M, 2015; Rojas, S., 2020; Danielson, Hankin, \& Badanes, 2015). Studies (Jolivet \& Randall, K., 2011; Brianna, N.,L., 2013; Norkiene,M., 2012) have shown that the potential psychological effects for these suffering children are chronic stress, insecurity, and agitation, sense of helplessness, and sense of rejection.

Mediation promotes a harmonious settlement of divorce agreement. This is opposed to the court settlement of a divorce case. The traditional role of a lawyer is to fight for the best interest of the client. The failure to consider other psychological and emotional factors will usually cause substantial damage to the parent's relationship (Danielson, Hankin, \& Badanes, 2015). Seeing this would shape a negative attitude of children to a marital relationship (Emery, R.E., and Wyer, M. M, 2015; Rojas, S., 2020; Norkiene,M., 2012). When the divorcing parents are determined to let the court decide on their rights, the way the court protects the children is by using the rule of the best interest of the children in deciding for the divorce-related right. This rule will balance the 'best interests' test with claims of parental rights. As claimed by Jolivet \& Randall, K., (2011), parents have a right to separate, divorce, and a right to direct the upbringing of their children, including the right to exclude others from that function. Settling the dispute through court procedures usually unlock the arrogant behavior while parties contested for custody, visitation, and adoption. The assertion of any of these rights may conflict with the children's best interests. Children's mind works like a videotape. The picture and action recorded may be rewind and replayed throughout their lives. This will have an impact on the psychological development of the children. The forming of a negative attitude to a marital relationship will later have an impact on the formation of a future society where these children live in.

\subsection{Best Interest of the Child}

The most critical issue relevant to divorce which will affect the children's emotional stability is the right of custody. There will be interference from the court if the parents could not settle the issues of custody amicably (Pheng,L.,M., 2010; Duff, I.,2010). The Guardianship of Infants Act 1961 provides for the equality of parental rights concerning the guardianship and upbringing of an infant or in the administration of property belonging to the children. Similarly, section 88(1) of the Law Reform (Marriage \& Divorce) Act 1976 (LRA) provides that the court may at any time by order place a child in the custody of his or her father or his or her mother. In deciding in whose custody children should be placed, the paramount consideration shall be the welfare of the children of 'the best interest of the children's rule' (Willemsen,E., 2012).

In the case of Rahanim v Adnan (1994) $9 \mathrm{JH} 216$, an attempt made by the father to disqualify the mother from the custodial claim was rejected by the court. The father has claimed that the mother was involved in immoral activities, but he failed to tender sufficient evidence in support of his claim. In another case, Mohamad Salleh v Azizah [1984] 4 JH 212 a mother who claimed that she was under post-natal syndrome objected to her consent of custodial right given to her ex-husband. The couple underwent another battle of the custodial claim that results in the mother winning back the custodial rights. Imagine the stressful pain that the children must resort to in these two cases. Knowing that the mother is immoral and confusion over the prolonged battle of custody. In the case of $M$ Saraswathi Devi a/p Govind v Keith lan Monteiro [2006] 3 MLJ 88, Low Hop Bing J. makes it mandatory for the court to consider the welfare of the children as being paramount and subject thereto, the wishes of the parents and the children.

Research conducted by (Jolivet \& Randall, K., (2011) has shown that children who must undergo their parents' divorce experience do not usually suffer a long-term critical psychological effect. However, what is more, detrimental to the children's long-term psychological 
effect is how the parents handle their divorce process. Emotional trauma which relates to the feeling of neglect and disrespect is reported to be the most common tension. Litigation over divorce cases may consume lengthy time (Ab Hak,N. 2008; Nor Fadzlina Nawi, N. F., 2011; Rashid, S.K, 2000). The uncertainties and the harm being done to the parent's relationship will have a damaging effect on the children's psychological development. Experts (Emery, R.E., and Wyer, M. M, 2015; Rojas, S., 2020; Norkiene,M., 2012) have identified potential sources of stress for children during the litigation of divorce case which is, parents involving the children in inter-parental conflict, parent and children have little control over legal events, disillusionment over the children's family and values will result in the diminishing of the marital relationship thus bring to the creation of a future society who prefers non-family community. This will later breed many other ethical and moral impeachments. Thus, Ab Hak,N. (2008) in her article suggested that family disputes should be settled through special procedures that mediation may provide to protect the children, who will be the most affected people during the pre and post-trial of such dispute.

\subsection{Mediation Practice in Malaysia}

The pre-divorce law in Malaysia provides for the need to attend a reconciliation session before hearing in court for a petition of divorce. (Section 55(1) of the Law Reform (Marriage \& Divorce) Act 1976). This has in a way acknowledged the role of a conciliator who is like a mediator. Nonetheless, the role of a mediator as proposed in this article states the need to extend the power of the mediator in helping to solve family disputes. Currently, with the enactment of the Mediation Act 2012, the practice of mediation has been legalised in Malaysia yet there is an absence of a compulsory requirement to direct couples in divorce cases to utilize mediation as the platform of settling divorce-related claims.

Mediation is a process beyond what a court can do to decide and how can a mediator help in coming out with a stylish decision (Abramson, H.J., 2011, Pheng,L.,M., 2010; Duff, I.,2010). Brown \& Mariot (1997) defined mediation as a facilitative process in which disputing parties engage the assistance of an impartial party in helping them to agree peacefully on their dispute. Goodman, A., \& Hammenton, A., (2006) stated that mediation is a voluntary, non-binding, and private dispute resolution process in which a neutral person helps the parties try to reach a negotiated settlement. The word voluntary means that it should not involve court binding rules (Ng, K., and et al., 2018; Chua,E., 2019). This definition can be said to have opposed to a court-annexed system. For Boulle L., (2005), mediation involves a decision making in which the parties are assisted by a third party. Abramson (2011) divides mediation into several categories which are facilitative, evaluative, transformative, bias, power, and problem-solving. The process is said to be less formal yet still structured and it encourages party's involvement. In proposing the workable model for Family Mediation in Malaysia, intensive training for a certified mediator is needed to understand their role in the settlement of divorce-related claims.

Litigation has a cost, not only for the litigants but for society, because judicial resources are limited, and their cost is usually born by the country (Ab Hak,N. 2008; Nor Fadzlina Nawi, N. F., 2011, Benny Riyanto,H.T, 2018). It is empowering for the parties that the principle of self-determination in mediation provides them with a high level of control over their dispute. This may encourage the willingness of divorcing parents to co-operate for the sake of their children (Ab Hak,N., 2008). This is a level of control that they would not experience in court (Phillips, 2010). On the other hand, by its very technical nature, litigation in many respects sometimes directs the client to the point where they do not fully understand what is happening. Mediation promotes neutrality and impartiality (Field,R., 2011). In contrast, Jolivet (2011) states that in an adversarial context, there is always a winner and loser. The winner-loser attitude will direct the parents to highlight the weaknesses of the contending party thus abandoning the children. Mediation is sought by the parties to avoid the glare of publicity and to keep their disputes low-key and private (Jolivet \& Randall, K.,2011). The discussions of the parties are confidential as are the terms of the settlements (Redfern, M., 2010). This is very suitable for family disputes as it seeks to preserve the close relationship. Mediation can be commenced as soon as the parties wish and do not involve complex, lengthy, or costly preparation. By comparison, litigation can be awfully expensive due to its rigorous and complicated process. On this point, not only that the training of mediator is important, but the couple in dispute should be educated on the role of mediator and the importance of the mediation process in arriving at a harmonious post-divorce agreement.

\subsection{Conclusion and Future Recommendations}

Divorce would affect the psychological development of children. The best that parents can do is minimize the effects. Mediation is formally recognized in helping to settle the commercial dispute. The enactment of the Mediation Act 2012 acknowledges mediation with this function. However, recognizing mediation as a medium to reconcile family disputes was not given equally. The family mediation practice should be adopted in the settlement of divorce cases in Malaysia emphasizing the development of a specified mediator training certification and educating the Malaysian family.

\section{Acknowledgments}

We would like to convey our sincere thanks to all respondents who have contributed directly or indirectly to this research. Our heart felt appreciation goes to the Faculty of Law, Universiti Teknologi MARA for the opportunity and financial assistance.

\section{Paper Contribution to Related Field of Study}

The outcome of the study may assist the government, policymaker, and legal practitioners in developing a harmonious platform to address family disputes that uphold the best interest of the children to divorce cases by adopting the family mediation practice. 


\section{Reference}

Ab Hak, N., (2008). Family Mediation: Its Characteristics and Process. Malayan Law Journal (MLJ)(4), xxxviii.

Abramson, H. J. (2011). Mediation Representation. Clarendon: The Oxford Press.

Alexander, N., (2019).Ten Trends in International Mediation. Singapore Academy of Law Journal(1)31, 405

Ali, S.F., (2019).Civil Mediation Reform: Balancing the Scale of Procedural and Substantive Justice. Civil Justice Quarterly(38) Issue 1, 20.

Baruch, R., and Folgen, J., (1994). Ideology, Orientation to Conflict, and Mediation Discourse in Joseph Folger \& Tricia Jones: New Directions in Mediation, Sage Publications.

Benny Riyanto, H. T. (2018). The Repositioning Mediation Court Model in Civil Dispute Resolution with Justice. Earth and Environmental Science 175, 12-18.

Boulle, L., (2005). Mediation: Principles, Process, Practice. (2nd edn.), Lexis-Nexis Butterworths.

Cetinkaya, S., and Erçin, E., (2015). The Psychological Problems Seen in the Children of Divorced Parents and the Nursing Approach Concerning These Problems. Submitted: (Open Access Book). DOI: 10.5772/59166 IntechOpen(Open Access Book).

Chua, E. (2019). Mediation in Singapore Family Justice Courts: Examining the Mandatory Mediation Model under the Judge-Led Approach. Civil Justice Quarterly volume 38 Issue 1, 50-62.

Field, R., (2010). FDR and Victims of Family Violence: Ensuring a Safe Process and Outcomes. Australasian Dispute Resolution Journal (21),53, 187.

Griffith, J. (2018, November 10). Psychological and Emotional Effects of Divorce on Children. Carlsbad, California, United States of America. Retrieved from https://www.gylfamilylawfirm.com/effects-of-divorce-on-children/.

Hammenton, A. G. (2006). Mediation Advocacy. UK: XPL Law.

Ismail, N., and Aziz, N.A., (2009, Jun 30-1 July). Sentence of a Children the Law and Psychological Perspectives. [The National Seminar on Children's Law, Terengganu Malaysia].

McDuff, I. (2010, November 23). The Dispute Resolution. (N. A. Aziz, Interviewer).

McGowan, D. (2018) Reframing the Mediation Debate in Irish All-Issues Divorce Disputes: From Mediation vs. Litigation to Mediation and Litigation. Journal of Social Welfare and Family Law, DOI:10.1080/09649069.2018.1444445.

Nawi, N.F., (2011, July 3-6). Mandating Mediation in Family Law Conflict in Malaysia: Exploring Judges and Lawyers Perspectives[ The 24th Annual International Association of Conflict Management Conference Istanbul, Turkey].

Ng,K., Yarni Loi, Y., Ang,S. and Sylvia Tan.S., (2018). Family Justice Courts-Innovations, Initiatives, and Programmes: An Evolution Over Time. Singapore Academy of Law Journal. (30),617.

Ojelabi, L.A.,(2019). Ethical Issues in Court-Connected Mediation.Civil Justice Quarterly(38) Issue 1, 62.

Owens, W., Wanda M., "The Behavioral Effects Divorce Can Have on Children" (2017).CUNY Academic Works.https://academicworks.cuny.edu/gc_etds/2314.

Pheng,L.M,(2010, November 23) The Mediation in Singapore.(N. A. Aziz, Interviewer).

Randall, J. (2011). The Psychological Impact of Divorce on Children: What is a Family Lawyer to Do. American Journal of Family Law volume 25, Issue 4, 215-222.

Rashid, S.K.,. (2000). Alternative Dispute Resolution in Malaysia. unpublished book- Kuala Lumpur, 2000.

Redfern.M., (2010). Mediation is Good Business Practice. Australasian Dispute Resolution Journal (21), 53.

Willemsen, E.,. (2012, November 16). The Best Interest of the Children. Santa Clara, California, United States of America. Retrieved from http://www.scu.edu/ethics/publications/iie. 